\title{
Akuntabilitas dan kinerja instansi pemerintah: Semu atau nyata?
}

\author{
Muhammad Ahyaruddin ${ }^{1}$, Rusdi Akbar ${ }^{2}$ \\ ${ }^{1}$ Fakultas Ekonomi dan Bisnis, Universitas Muhammadiyah Riau, Pekanbaru, Indonesia \\ ${ }^{2}$ Fakultas Ekonomika dan Bisnis, Universitas Gadjah Mada, Yogyakarta, Indonesia \\ e-mail: ${ }^{1}$ ahyaruddin@umri.ac.id; ${ }^{2}$ rusdi.akbar@ugm.ac.id
}

\section{A R T I K E L I N F O}

\section{Article history:}

Available online

Keywords:

Accountability, Local Government Performance, Mixed Methods, Institutional Isomorphism

\section{A B S T R A C T}

This research aims to analyze factors driving the accountability and performance of government as well as exploring qualitatively about accountability and performance of government agencies. In particular, this study examines the effect of incentives, regulations, and management commitment on government accountability and performance. Mixed method approach was used to answer research questions. Hypotheses were tested using SEM-PLS. Data analysis of the study involved 137 SKPD officers in districts/cities in Yogyakarta Special Region (DIY) and five respondents as key informants. The results of the study found that management commitment has significant effect on accountability and government performance. In addition, regulatory also have significant effect on accountability. The findings also reveal the coercive pressure that exists in implementing accountability and government performance. This concludes that reporting of accountability and government performance in DIY was only limited to the formalities to meet regulatory obligations, so that this indicates a pseudo-performance. In the context of institutional theory, this study demonstrates significant contribution to the development of institutional isomorphism in public sector organizations, particularly local governments.

\begin{abstract}
A B S T R A K
Penelitian ini bertujuan untuk menganalisis faktor-faktor pendorong akuntabilitas dan kinerja pemerintah serta mengeksplorasi secara kualitatif tentang akuntabilitas dan kinerja instansi pemerintah. Secara khusus, penelitian ini menguji pengaruh insentif, regulasi, dan komitmen manajemen terhadap akuntabilitas dan kinerja pemerintah. Pendekatan metode campuran digunakan untuk menjawab pertanyaan penelitian. Hipotesis diuji dengan menggunakan SEM-PLS. Analisis data penelitian melibatkan 137 pejabat SKPD di kabupaten/kota di Daerah Istimewa Yogyakarta (DIY) dan lima responden sebagai informan kunci. Hasil penelitian menemukan bahwa komitmen manajemen berpengaruh signifikan terhadap akuntabilitas dan kinerja pemerintah. Selain itu, regulasi juga berpengaruh signifikan terhadap akuntabilitas. Temuan penelitian ini juga mengungkap adanya tekanan koersif yang terjadi dalam pelaksanaan akuntabilitas dan kinerja pemerintah. Hal ini menyimpulkan bahwa pelaporan akuntabilitas dan kinerja pemerintah di DIY hanya sebatas formalitas untuk memenuhi kewajiban regulasi dan mengindikasikan terjadinya kinerja semu. Dalam konteks teori institusional, penelitian ini menunjukkan kontribusi terhadap pengembangan konsep isomorfisma institusional pada organisasi sektor publik, khususnya pemerintah daerah.
\end{abstract}

\section{Pendahuluan}

Semangat reformasi pada tahun 1998/1999 yang terjadi di Indonesia berdampak pada perubahan dalam berbagai bidang. Salah satunya adalah perubahan tata kelola pemerintahan dari tradisional menuju konsep New Public Management (NPM). Menurut Christensen dan Lægreid (2014), konsep NPM dipandang sebagai salah satu konsep yang bisa meningkatkan efisiensi sektor publik, meningkatkan respon lembaga-lembaga publik terhadap masyarakat, serta diharapkan bisa meningkatkan akuntabilitas dan kinerja pemerintah. Sebagai wujud komitmen pemerintah dalam mendukung reformasi birokrasi maupun reformasi di bidang pengelolaan keuangan, pemerintah menerbitkan instruksi presiden nomor 7 tahun 1999 tentang Laporan Akuntabilitas Kinerja Instansi Pemerintah (LAKIP). LAKIP ini merupakan salah satu bentuk pertanggungjawaban pemerintah kepada publik yang berisi informasi mengenai keberhasilan pelaksanaan program maupun kegiatan. 
Salah satu bentuk derivasi dari kewajiban instansi pemerintah untuk membuat LAKIP adalah perlu adanya sistem pengukuran kinerja yang baik dan memadai. Sistem pengukuran kinerja ini harus dilaksanakan secara sistematis dan berkesinambungan untuk menciptakan pengelolaan organisasi yang optimal, bersih, dan bertanggung jawab (Ahyaruddin dan Akbar 2018). Christensen dan Lægreid (2014) mengemukakan bahwa sistem pengukuran kinerja yang dijalankan dengan baik dan sesuai oleh pemerintah akan lebih mudah dalam melakukan efisiensi dan efektifitas layanan publik, serta alokasi sumber daya dan pembuatan keputusan yang pada akhirnya dapat meningkatkan akuntabilitas dan kinerja organisasi. Namun, Nurkhamid (2008) mengungkapkan bahwa realitas yang selama ini terjadi pada instansi pemerintah adalah bahwa akuntabilitas dan kinerja yang dihasilkan masih bersifat semu dan cenderung bias bahkan sering dipertanyakan. Instansi pemerintah memiliki kecenderungan untuk melaporkan kinerja yang baik secara berlebihan, sedangkan program yang gagal cenderung disembunyikan (Nurkhamid 2008). Laporan kinerja yang selama ini dibuat oleh instansi pemerintah hanya sekedar untuk memenuhi kewajiban persyaratan regulasi dan peraturan, tidak secara substantif mencerminkan kinerja yang terjadi di lapangan. Hal ini kemudian bisa menyesatkan publik sebagai pengguna informasi dan pada akhirnya berakibat pada ekspektasi publik yang berlebihan terhadap instansi pemerintah (Ahyaruddin dan Akbar 2018, 2016).

Beberapa hasil penelitian terakhir yang menggunakan teori institusional mengungkapkan bahwa alasan utama yang mendasari perubahan organisasi adalah hanya sekedar untuk mendapatkan legitimasi daripada meningkatkan kinerja secara substantif (Chenhall 2003); Ashworth et al. 2009; Akbar et al. 2012; Sofyani dan Akbar 2013; Wijaya dan Akbar 2013; Akbar et al. 2015; Ahyaruddin dan Akbar 2016; 2018). Hal ini mengindikasikan bahwa pelaporan akuntabilitas kinerja yang selama ini dilaporkan oleh organisasi pemerintah melalui LAKIP cenderung sebatas formalitas untuk memenuhi kewajiban regulasi karena hanya untuk mendapatkan dukungan politik dan legitimasi. Namun demikian, hal ini perlu dibuktikan secara empiris. Oleh karena itu, penelitian ini dilakukan dengan tujuan untuk menganalisis faktor-faktor pendorong akuntabilitas dan kinerja pemerintah serta mengeksplorasi secara kualitatif apa yang terjadi sesungguhnya terkait dengan akuntabilitas dan kinerja instansi pemerintah. Beberapa faktor yang diduga berpengaruh terhadap akuntabilitas dan kinerja instansi pemerintah misalnya: insentif, regulasi, dan komitmen manajemen (Newberry dan Pallot 2004; Cavalluzzo dan Ittner 2004; Sofyani dan Akbar 2013; Manafe dan Akbar 2014; Speklé dan Verbeeten 2014; Akbar et al. 2015; Ahyaruddin dan Akbar 2016). Namun, faktor-faktor yang diungkapkan oleh beberapa hasil penelitian tersebut masih memberikan ruang perdebatan. Sehingga penelitian lanjutan dengan pendekatan yang lebih komprehensif perlu dilakukan untuk memberikan hasil yang robust. Terlebih lagi, penelitian ini penting karena mengeksplorasi secara lebih mendalam dua pertanyaan kualitatif berikut: (1) apakah isomorfima koersif yang terjadi dalam praktik akuntabilitas dan kinerja instansi pemerintah menyebabkan kinerja semu?; (2) Apakah informasi dalam LAKIP digunakan dalam proses pengambilan keputusan oleh instansi pemerintah?

Penelitian ini memberikan kontribusi secara teoritis dibidang literatur akuntansi sektor publik khususnya terkait dengan akuntabilitas, kinerja, maupun institutional theory dengan menghubungkan tiga mekanisme isomorphism yaitu: coercive, mimetic, dan normative. Penelitian ini juga memberikan kontribusi terhadap metodologi penelitian dibidang akuntansi sektor publik dengan menunjukkan manfaat menggunakan metode penelitian campuran (mixed-method research) daripada hanya menggunakan satu pendekatan metode penelitian. Terakhir, secara praktis, penelitian ini memberikan informasi yang berguna bagi pelaku organisasi sektor publik terutama pemerintah terkait dengan faktor-faktor pendorong yang dapat meningkatkan akuntabilitas dan kinerja secara substantif, bukan hanya sekedar kinerja semu.

\section{Tinjauan Pustaka dan Perumusan Hipotesis}

\section{Teori Institusional}

Banyak penelitian pada organisasi sektor publik menggunakan teori institusional (institutional theory) sebagai acuan untuk menjelaskan struktur maupun perubahan organisasi. Beberapa penelitian yang menggunakan teori institusional dalam konteks organisasi sektor publik khususnya di Indonesia, misalnya: Akbar et al. 2012; Wijaya dan Akbar 2013; Sofyani dan Akbar 2015, 2013; Manafe dan Akbar 2014; Primarisanti dan Akbar 2015; Akbar et al. 2015; Ahyaruddin 2015; dan Ahyaruddin dan Akbar 2016, 2018).

Pandangan dalam teori institusional menjelaskan tentang struktur organisasi dimana sebuah organisasi mengadopsi sesuatu yang sesuai (conformity) dengan kode etik budaya yang kemudian mengarah pada legitimasi dan dukungan dari organisasi eksternal (Dimaggio dan Powell 1983; Ahyaruddin dan Akbar 2016, 2018). Dalam teori ini, suatu organisasi cenderung bergerak ke arah homogenisasi, meskipun pada awalnya mereka menunjukkan adanya keragaman yang cukup besar (Dimaggio dan Powell 1983). Istilah yang tepat untuk menggambarkan proses homogenisasi tersebut adalah isomorfisma. 
Dimaggio dan Powell (1983) mengemukakan bahwa isomorfisma terdiri dari isomorfisma kompetitif yang terkait dengan efisiensi (penjelasan teknis atau ekonomis) serta isomorfisma institusional yang berkembang sesuai dengan tiga mekanisme, yaitu koersif, mimetik, dan normatif. Dalam konsep isomorfisma kompetitif, dikatakan bahwa ketika ada suatu cara yang lebih murah, lebih baik, atau lebih efisien dalam melakukan sesuatu, kekuatan kompetitif mendorong organisasi untuk menuju ke arah pendekatan baru tersebut. Sementara itu, dalam konsep isomorfisma institusional, pengaruh institusional tersebar melalui area organisasi yang disebut dengan medan organisasi, yang berarti bahwa organisasi-organisasi secara keseluruhan merupakan sebuah area yang diakui dari kehidupan institusional, yaitu pemasok kunci, sumberdaya dan pelanggan produk, ketergantungan peraturan, dan organisasi lain yang menyediakan layanan dan produk serupa (Erro dan Sánchez 2012). Isomorfisma struktural digambarkan sebagai sebuah konsekuensi penting dari proses kompetitif dan institusional. Akibatnya, organisasi tidak bersaing untuk mendapatkan sumber daya atau pelanggan tetapi untuk mendapatkan kekuasaan dan legitimasi, selain untuk kesejahteraan sosial dan hasil ekonomi (Dimaggio dan Powell 1983; Erro dan Sánchez 2012; Akbar et al. 2012; Ahyaruddin dan Akbar 2016, 2018).

\section{Konsep Akuntabilitas}

Istilah akuntabilitas bisa didefinisikan dalam banyak perspektif dan mengalami perubahan dari waktu ke waktu. Banyak peneliti mendefinisikan akuntabilitas sesuai dengan konteks dan kondisi masing-masing. Dalam konteks organisasi sektor publik, Inaga (1991) seperti yang dikutip oleh Iyoha dan Oyerinde (2010) mengatakan bahwa akuntabilitas mensyaratkan pemerintah untuk memberikan suatu alasan terkait dengan sumber dan penggunaan/pemanfaatan sumberdaya publik. Sehingga akuntabilitas dalam hal ini adalah terkait dengan pengawasan dan pengendalian perilaku pemerintah, mencegah pembangunan konsentrasi kekuasaan, dan meningkatkan kemampuan belajar dan efektifitas administrasi publik (Iyoha dan Oyerinde 2010). Dalam sistem pemerintahan konstitusional, ada dua jenis akuntabilitas, yaitu: (1) akuntabilitas internal, yang merupakan sebuah tipe akuntabilitas langsung yang berlaku dalam sistem organisasi tertentu dan melibatkan pelaporan langsung dari bawahan kepada atasan yang memegang kekuasaan, dan (2) akuntabilitas eksternal, yang merupakan tipe akuntabilitas tidak langsung yang melibatkan pelaporan kepada pihak luar organisasi (Matek 1977 dalam Akbar 2011).

Roberts dan Scapens (1985) seperti yang dikutip oleh Sinclair (1995) mengatakan bahwa akuntabilitas mensyaratkan sebuah hubungan dimana seseorang diminta untuk menjelaskan dan mengambil tanggungjawab terhadap tindakan mereka. Sinclair (1995) mengatakan bahwa bagaimana akuntabilitas tersebut didefinisikan akan tergantung pada ideologi, motif dan bahasa zaman kita. Lebih lanjut, Sinclair (1995) mengatakan bahwa akuntabilitas memiliki disiplin makna khusus dan dapat didefinisikan dari berbagai perspektif. Sebagai contoh, seorang auditor membahas akuntabilitas seolah-olah terkait dengan masalah keuangan atau numerik, sedangkan seorang ilmuwan politik memandang akuntabilitas sebagai suatu keharusan politik dan mahasiswa hukum memandang sebagai sebuah pengaturan konstitusional, sementara seorang filsuf memandang akuntabilitas sebagai bagian dari etika (Iyoha dan Oyerinde 2010).

Definisi yang dikemukakan oleh Sinclair (1995) terkait dengan akuntabilitas dibagi menjadi lima bentuk akuntabilitas, yaitu: (1) akuntabilitas politik, (2) akuntabilitas publik, (3) akuntabilitas manajerial, (4) akuntabilitas profesional, dan (5) akuntabilitas personal. Akuntabilitas politik berasal dari tradisi demokrasi orang Athena dan Westminster. Dalam konsep ini, pejabat organisasi publik melaksanakan kewenangan atas nama wakil rakyat terpilih, yang pada gilirannya bertanggung jawab langsung kepada rakyat (Day \& Klein 1987 dalam Akbar 2011). Dalam pemerintahan yang demokratis (misalnya Indonesia), para pejabat eksekutif secara resmi melepaskan akuntabilitas mereka kepada para politisi di parlemen sebagai wakil rakyat (Sinclair 1995).

Sementara itu, akuntabilitas publik hampir mirip dengan akuntabilitas politik, tetapi lebih bersifat informal dan akuntabilitas ini secara langsung berhadapan dengan publik, individu, maupun kelompok masyarakat. Akuntabilitas publik melibatkan berbagai mekanisme yang tersedia untuk menjelaskan kebijakan dan kegiatan organisasi seperti dengar pendapat publik, penyediaan laporan pemerintah di media massa, atau bahkan melalui alat komunikasi real time yang memungkinkan orang untuk berkomunikasi kepada pejabat pemerintah dengan mudah dan langsung (Sinclair 1995; Akbar 2011). Sedangkan akuntabilitas manajerial dilihat berfokus pada pengawasan input dan output atau outcome. Dalam konsep akuntabilitas manajerial, hubungan akuntabilitas juga ditemukan di dalam organisasi itu sendiri. Akuntabilitas manajerial dalam hal ini terkait dengan adanya tanggungjawab dari pejabat yang lebih rendah kepada pejabat yang lebih tinggi atas pelaksanaan tugas yang telah didelegasikan (Akbar 2011).

Selanjutnya adalah akuntabilitas profesional yang terkait dengan adanya panggilan atau rasa kewajiban yang dimiliki seseorang sebagai anggota dari kelompok profesional atau ahli, yang kemudian menempati posisi istimewa dan berpengetahuan dalam masyarakat (Sinclair 1995). Dalam hal ini, pegawai pemerintah dan pejabat 
diharuskan bertindak dan berperilaku secara profesional untuk memberikan pelayanan yang terbaik dan mereka dapat memberikan manfaat berdasarkan keterampilan dan keahlian yang mereka miliki (Akbar 2011). Terakhir adalah akuntabilitas personal. Konsep dari akuntabilitas personal ini berkaitan dengan tanggung jawab individu dan poin akhir dari bentuk akuntabilitas. Akuntabilitas ini terletak pada kepatuhan hati nurani pribadi sebagai konsekuensi logis dari internalisasi nilai-nilai moral dan etika, misalnya menghormati martabat manusia, dan bertindak dengan cara menerima tanggungjawab untuk mempengaruhi kehidupan orang lain (Sinclair 1995; Akbar 2011).

\section{Penelitian Terdahulu dan Pengembangan Hipotesis}

Teori kelembagaan menunjukkan bahwa regulasi (atau mandat legislatif) merupakan faktor organisasi yang relevan dengan keberhasilan pelaksanaan reformasi di organisasi pemerintah (Brignall dan Modell 2000). Akbar et al. (2012) dalam penelitiannya juga menemukan bahwa mandat legislatif memiliki hubungan positif terhadap akuntabilitas internal dan eksternal. Dalam konteks organisasi sektor publik di Indonesia, mandat legislatif yang ada adalah terkait dengan regulasi dan peraturan. Setiap organisasi pemerintah wajib mematuhi peraturan maupun undang-undang yang dibuat oleh pemerintah. Sehingga dalam hal ini peraturan ataupun regulasi tersebut bersifat memaksa bagi suatu organisasi untuk melaksanakannya.

Berdasarkan hal tersebut, maka bisa dikatakan bahwa konsep isomorphism khususnya mekanisme pemaksaan (coercive) seperti yang diungkapkan oleh Dimaggio dan Powell (1983) mungkin terjadi dalam praktek organisasi sektor publik di Indonesia. Apalagi hal ini diperkuat dengan hasil penelitian Talbot (2008) pada organisasi sektor publik di Inggris yang mengungkapkan bahwa para manajer publik menilai undang-undang (regulasi) sebagai salah satu penggerak utama suatu perubahan. Sehingga dalam hal ini regulasi dianggap menjadi aspek penting dalam keberhasilan inovasi sehubungan dengan praktik akuntabilitas dan kinerja instansi pemerintah. Oleh karena itu, penulis merumuskan hipotesis sebagai berikut:

$\mathrm{H}_{1}$ : Regulasi berhubungan positif terhadap akuntabilitas

$\mathrm{H}_{2}$ : Regulasi berhubungan positif terhadap kinerja

Komitmen manajemen merupakan salah satu faktor yang sangat penting dalam mendorong perwujudan akuntabilitas dan kinerja organisasi sektor publik. Komitmen manajemen merupakan kelekatan emosi maupun bentuk loyalitas dari orang-orang yang tergabung dalam organisasi untuk mencurahkan perhatian, gagasan, dan tanggungjawabnya dalam rangka mencapai misi, nilai-nilai, dan tujuan organisasi (Primarisanti dan Akbar 2015). Akuntabilitas dan kinerja organisasi akan bisa terwujud dengan baik apabila terdapat dukungan dan komitmen dari seluruh unsur yang dalam dalam organisasi, mulai dari level puncak, menengah, sampai di level bawah. Ada dua karakteristik penting dari komitmen manajemen atau organisasi, yaitu keyakinan kuat dan penerimaan dari nilai-nilai dan tujuan organisasi, dan sebuah kemauan untuk mengerahkan segala usaha atas nama organisasi (Porter et al. 1974; Angle dan Perry 1981 dalam Sholihin dan Pike 2009).

Beberapa penelitian empiris mengungkapkan bahwa komitmen manajemen bisa mengarah pada peningkatan kinerja maupun akuntabilitas. Sholihin dan Pike (2009) dalam penelitiannya menemukan hasil bahwa komitmen organisasi secara positif berhubungan terhadap kinerja. Kemudian Cavalluzzo dan Ittner (2004) mengatakan bahwa komitmen manajemen berpengaruh positif terhadap pengembangan indikator kinerja, akuntabilitas kinerja dan penggunaan informasi kinerja yang dihasilkan oleh implementasi sistem pengukuran kinerja. Sementara itu, penelitian yang dilakukan oleh Akbar et al. (2012) mengatakan bahwa komitmen manajemen berpengaruh positif terhadap akuntabilitas internal dan ekternal. Begitu juga dengan hasil penelitian Primarisanti dan Akbar (2015), yang menemukan bahwa komitmen manajemen berpengaruh positif tehadap akuntabilitas kinerja. Oleh sebab itu, penulis dalam penelitian ini merumuskan hipotesis yaitu:

$\mathrm{H}_{3}$ : Komitmen manajemen berhubungan positif terhadap akuntabilitas

$\mathrm{H}_{4}$ : Komitmen manajemen berhubungan positif terhadap kinerja

Berbagai penelitian tentang inisiatif NPM didasarkan pada asumsi bahwa peningkatan akuntabilitas akan meningkatkan kinerja (Christensen dan Lægreid 2014). Akuntabilitas merupakan sebuah gagasan yang kompleks dan beraneka ragam, sehingga kemungkinan pengaruh akuntabilitas terhadap kinerja masih menjadi perdebatan dan inkonklusif, paling tidak karena kinerja sangat kompleks, beraneka ragam, dan sulit diukur (Demirag dan Khadaroo 2011; Hyndman dan Eden 2001). Meskipun demikian, akuntabilitas di dalam konsep NPM seringkali dirasakan sebagai sebuah alat untuk meningkatkan kemampuan pemerintah dalam memberikan barang dan jasa/pelayanan publik, yaitu kemampuannya untuk menunjukkan kinerja secara lebih efisien dan efektif (Dubnick 2005; Demirag dan Khadaroo 2011). 
Schillemans (2011) mengatakan bahwa meningkatkan akuntabilitas horizontal dari lembaga ekskutif mungkin bisa meningkatkan pembelajaran organisasional tetapi tidak pada pengendalian demokrasi. Pollitt (2008) meneliti secara kritis proposisi bahwa sistem manajemen kinerja akan meningkatkan akuntabilitas lembaga terhadap rakyat dan perwakilan politik. Penelitiannya menggunakan dua studi kasus yaitu National Health Service di United Kingdom dan World Governance Indicators Bank Dunia. Hasil penelitiannya menyimpulkan bahwa pengukuran kinerja belum dapat meningkatkan akuntabilitas politik. Tetapi beberapa peneliti menolak asumsi bahwa akuntabilitas semestinya memiliki dampak positif dan negatif. Sedangkan Dubnick (2005) mengatakan ide bahwa akuntabilitas meningkatkan kinerja telah diterima tanpa dilakukan penelitian dengan cermat dan dia mengklaim bahwa terdapat sebuah "paradoks akuntabilitas" dimana akuntabilitas secara aktual menurunkan kinerja organisasi. Berdasarkan penjelasan di atas, peneliti mencoba merumuskan hipotesis kedelapan, yaitu:

$\mathrm{H}_{5}$ : Akuntabilitas berhubungan positif terhadap kinerja

Peran insentif memiliki kehadiran utama dalam bahasa new public management (NPM) yang berusaha untuk menerapkan prinsip-prinsip dan praktik manajemen dari market sector terhadap pemerintah (Newberry dan Pallot 2004). Untuk mempromosikan efisiensi, efektifitas, dan akuntabilitas sektor publik, NPM mendorong sebuah mekanisme gagasan kontrak kinerja (performance contracting) dimana target kinerja yang jelas dan terukur harus bisa membimbing usaha pelayan masyarakat (civil servant) menuju pencapaian tujuan organisasi. Dalam pandangan ini, sistem pengukuran kinerja diharuskan untuk menciptakan insentif yang bisa membantu menyelaraskan tujuan individu dengan tujuan organisasi, memberikan informasi umpan balik yang berharga terhadap kemajuan pencapaian tujuan tersebut, dan membentuk suatu dasar bagi akuntabilitas internal dan eksternal (Cavalluzzo dan Ittner 2004; Speklé dan Verbeeten 2014)

Newberry dan Pallot (2004) mengatakan bahwa penggunaan sistem pengukuran kinerja yang berorientasi insentif (incentive-oriented use) merupakan suatu program NPM yang menekankan pada peran sistem pengukuran kinerja dalam penyusunan target, pemberian insentif, dan penghargaan (rewards) (Speklé dan Verbeeten 2014). Hasil penelitian Speklé dan Verbeeten (2014) mengungkapkan bahwa penggunaan sistem pengukuran kinerja yang berorientasi insentif (incentive oriented use) akan mempengaruhi kinerja. Sementara itu, Hansen dan Mowen (2006) mengatakan bahwa pemberian insentif berhubungan erat dengan kinerja. Sasarannya adalah untuk menciptakan kesesuaian tujuan, sehingga manajer akan menunjukkan kinerja terbaiknya bagi perusahaan ataupun organisasi. Hal yang sama juga diungkapkan oleh Ichniowski et al. (1997) yang mengatakan bahwa kinerja yang tinggi pada dasarnya tergantung pada program pemberian insentif jika dihubungkan dengan pekerjaan yang mendukung, yang meliputi penilaian kerja, informasi yang merata, dan keamanan kerja. Pemberian insentif merupakan salah satu motivasi yang lebih kuat bagi karyawan untuk meningkatkan kualitas kinerjanya. Maka berdasarkan penjelasan di atas, peneliti merumuskan hipotesis sebagai berikut:

$\mathrm{H}_{6}$ : Insentif berhubungan positif terhadap Kinerja

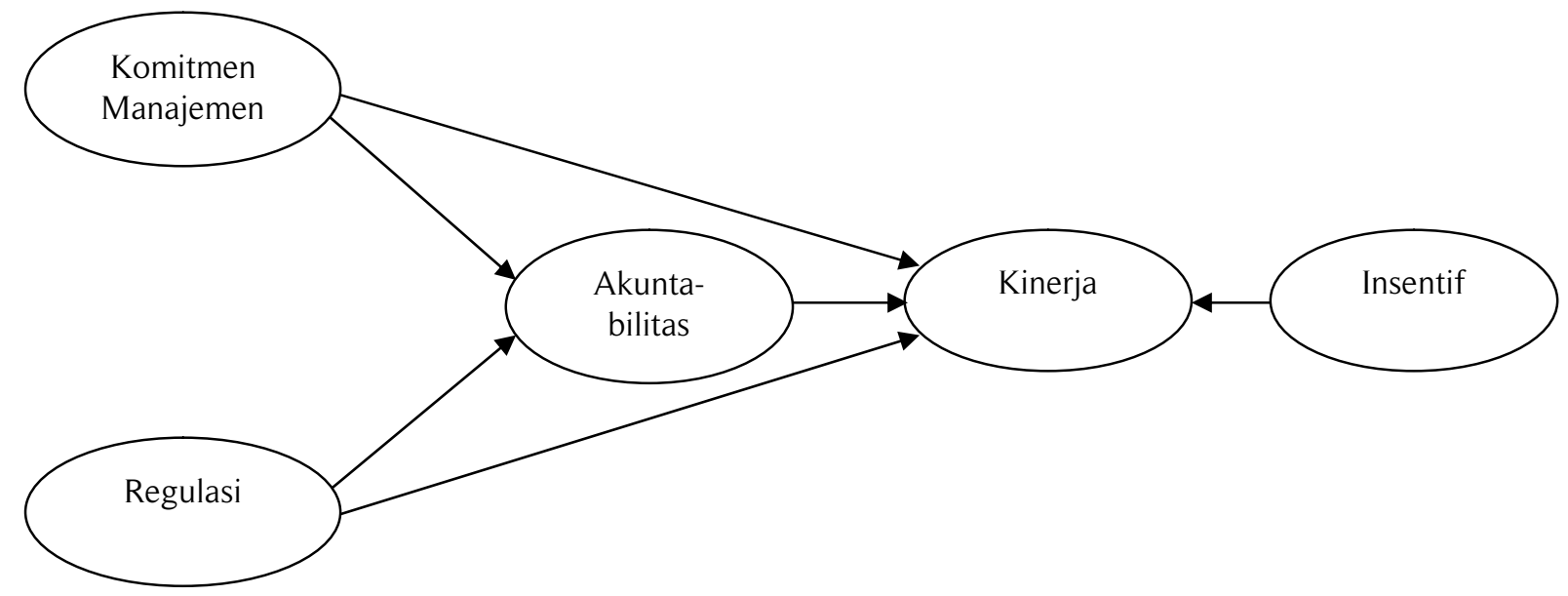

Gambar 1. Model Penelitian

\section{Metoda Penelitian}

\section{Data dan Sampel}

Penelitian ini menggunakan pendekatan metode campuran dengan desain sekuensial eksplanatori. Pendekatan ini dianggap lebih cocok digunakan untuk meng-capture berbagai hal dan situasi secara lebih detail daripada hanya 
menggunakan satu pendekatan kuantitatif ataupun kualitatif saja (Creswell dan Clarke 2011). Langkah yang dilakukan pada metode campuran melibatkan dua tahap, yaitu: tahap pertama melibatkan pengumpulan dan analisis data kuantitatif. Kemudian berdasarkan hasil kuantitatif yang telah dilakukan, peneliti mengimplementasikan tahap kedua yaitu pengumpulan dan analisis data kualitatif yang bertujuan untuk menjelaskan lebih dalam temuan/hasil dari tahap kuantitatif. Teknik analisis data kuantitatif menggunakan berbagai pengujian statistik inferensial seperti uji validitas, reliabilitas, statistik deskriptif, dan juga analisis multivariat. Pengujian hipotesis dilakukan dengan pendekatan Structural Equation Modelling - Partial Least Square (SEM-PLS) menggunakan software WarpPLS 3.0. Sedangkan teknik analisis data kualitatif menggunakan analisis isi tematik.

Sampel penelitian ini adalah eksekutif senior pada Satuan Kerja Perangkat Daerah (SKPD) di lingkungan pemerintah kabupaten/kota di Daerah Istimewa Yogyakarta (DIY). Data Jumlah sampel diperoleh dan diakses melalui situs resmi pada masing-masing pemerintah kabupaten/kota yaitu Kota Yogyakarta, Kabupaten Sleman, Kabupaten Bantul, Kabupaten Kulonprogo, dan Kabupaten Gunungkidul.

\section{Definisi dan Pengukuran Variabel}

Variabel kinerja dalam penelitian ini diukur dengan menggunakan instrumen dari Speklé dan Verbeeten (2014) yang dikembangkan sebelumnya oleh Price et al. (1981). Instrumen tersebut secara khusus didesain untuk mengukur kinerja di organisasi sektor publik dan telah digunakan dalam beberapa penelitian sebelumnya, seperti penelitian oleh Williams et al. (1990), Dunk dan Lysons (1997), Verbeeten (2008), dan Speklé dan Verbeeten (2014). Dimensi kinerja meliputi: (1) produktivitas, (2) kualitas atau keakuratan pekerjaan yang dihasilkan, (3) jumlah inovasi, perbaikan proses (process improvements), atau ide-ide baru, (4) reputasi untuk keunggulan kerja, (5) pencapaian produksi ataupun service level goals, (6) efisiensi operasi, dan (7) semangat personel unit. Responden dalam hal ini diminta untuk mengindikasikan skor dari unit organisasinya pada masing-masing dimensi kinerja tersebut dengan memberikan poin dalam bentuk skala likert 1-5 (1 = jauh dibawah rata-rata, $5=$ jauh diatas rata-rata) (Speklé dan Verbeeten 2014).

Variabel akuntabilitas menggunakan dua konsep akuntabilitas yang digunakan dalam penelitian Akbar et al. (2012), yaitu akuntabilitas internal dan akuntabilitas eksternal. Akuntabilitas internal merupakan sebuah tipe akuntabilitas langsung yang berlaku dalam sistem organisasi tertentu dan melibatkan pelaporan langsung dari bawahan kepada atasan yang memegang kekuasaan. Sedangkan akuntabilitas eksternal merupakan tipe akuntabilitas tidak langsung yang melibatkan pelaporan kepada pihak luar organisasi (Matek 1977 dalam Akbar 2011). Variabel akuntabilitas dalam penelitian ini diukur dengan menggunakan skala likert 1-5 yang terdiri dari beberapa konstruk pernyataan. Instrumen tersebut diadopsi dari Cavalluzzo dan Ittner (2004), Akbar et al. (2012), dan Wang (2002) dengan beberapa penyesuaian berdasarkan konteks Indonesia.

Variabel insentif dalam penelitian ini terkait dengan sistem pengukuran kinerja yang ditujukan untuk penggunaan insentif dan diukur dengan menggunakan kategori metrik kinerja. Instrumen yang digunakan diadopsi dari penelitian Speklé dan Verbeeten (2014) dan diukur dengan menggunakan skala likert 1-5. Variabel komitmen manajemen digunakan untuk mengukur seberapa intensif para pejabat organisasi sektor publik berkomitmen dalam rangka untuk meningkatkan akuntabilitas dan kinerja organisasi. Variabel ini diukur dengan menggunakan skala likert 1-5 berdasarkan item-item pertanyaan yang mengacu pada instrumen Cavalluzzo dan Ittner (2004) dan Nurkhamid (2008). Variabel regulasi (mandat legislatif) terkait dengan keterlibatan staf maupun pimpinan dalam aktifitas yang berhubungan dengan laporan akuntabilitas kinerja instansi pemerintah (LAKIP). Variabel ini diukur dengan skala likert 1-5 menggunakan item-item pertanyaan dari instrumen Akbar et al. (2012).

\section{Hasil dan Pembahasan}

\section{Statistik Deskriptif}

Penelitian ini merupakan penelitian survei dalam bentuk pengiriman kuisioner kepada responden. Sebanyak 137 responden yang diteliti terdiri dari pejabat eselon dua, tiga dan empat dari lima kabupaten/kota di DIY. Sampel yang ada terdiri dari 26 responden dari Kabupaten Sleman, 33 dari Kabupaten Bantul, 39 dari Kota Yogyakarta, 15 dari Kabupaten Kulonprogo, dan 24 dari Kabupaten Gunungkidul. Responden yang di survei terdiri dari lakilaki sebanyak 72, perempuan 51 dan sisanya sebanyak 14 tidak diketahui karena tidak menjawab pertanyaan terkait jenis gender. Rata-rata responden yang diteliti sudah berpengalaman dibidangnya terlihat dari pengalaman kerja mereka yang sudah lebih dari 15 tahun yaitu sebanyak 73\%. Gambaran detil responden bisa dilihat pada Tabel 1. 
Tabel 1. Karakteristik Demografi Responden (N=137)

\begin{tabular}{|c|c|c|c|}
\hline \multicolumn{2}{|c|}{ Karakteristik Responden } & \multirow{2}{*}{$\begin{array}{c}\text { Jumlah } \\
39\end{array}$} & \multirow{2}{*}{$\begin{array}{r}\text { Persentase } \\
28.4 \%\end{array}$} \\
\hline Daerah & - Yogyakarta & & \\
\hline & - Sleman & 26 & $19 \%$ \\
\hline & - Gunungkidul & 24 & $17.5 \%$ \\
\hline & - Kulonprogo & 15 & $11 \%$ \\
\hline & - Bantul & 33 & $24.1 \%$ \\
\hline \multirow[t]{3}{*}{ Jenis Kelamin } & - Laki-laki & 72 & $52.6 \%$ \\
\hline & - Perempuan & 51 & $37.2 \%$ \\
\hline & - Tidak Menjawab & 14 & $10.2 \%$ \\
\hline \multirow[t]{4}{*}{ Jabatan } & - $\quad$ Eselon II & 4 & $2.9 \%$ \\
\hline & - Eselon III & 36 & $26.3 \%$ \\
\hline & - Eselon IV & 79 & $57.7 \%$ \\
\hline & - Tidak Menjawab & 18 & $13.1 \%$ \\
\hline \multirow[t]{5}{*}{ Kelompok Umur } & - $\quad<30$ & 4 & $2.9 \%$ \\
\hline & - $\quad 30-40$ & 15 & $11 \%$ \\
\hline & - $\quad 41-50$ & 63 & $46 \%$ \\
\hline & - $\quad>50$ & 40 & $29.2 \%$ \\
\hline & - Tidak Menjawab & 15 & $10.9 \%$ \\
\hline \multirow[t]{6}{*}{ Pengalaman Kerja } & - $<2$ & - & - \\
\hline & - $2-5$ & 3 & $2.2 \%$ \\
\hline & - $6-10$ & 4 & $2.9 \%$ \\
\hline & - $11-15$ & 16 & $11.7 \%$ \\
\hline & - $\quad>15$ & 100 & $73 \%$ \\
\hline & - Tidak Menjawab & 14 & $10.2 \%$ \\
\hline
\end{tabular}

\section{Hasil Uji Realibilitas}

Penelitian ini menggunakan analisis persamaan struktural dalam menjawab hipotesis yang diajukan. Namun, beberapa syarat harus dipenuhi terlebih dahulu sebelum pengujian tersebut dilakukan, yaitu uji validitas dan reliabilitas. Hasil pengujian validitas yang telah dilakukan berdasarkan uji validitas konvergen dan validitas diskriminan telah memenuhi standar minimal dengan nilai faktor loading di atas 0.50 dan p-value di bawah 0.05. Sehingga seluruh konstruk dinyatakan valid dan layak untuk dilakukan analisis lebih lanjut. Hasil pengujian reliabilitas juga menunjukkan semua konstruk telah memenuhi reliabilitas konsistensi internal yang dilihat dari nilai reliabilitas komposit dan cronbach's alpha di atas 0,70. Nilai tertinggi untuk reliabilitas komposit adalah konstruk regulasi yaitu sebesar 0.961 , sedangkan nilai terendah adalah konstruk kinerja yaitu sebesar 0.903 (lihat Tabel 2).

Tabel 2. Hasil Uji Reliabilitas Konsistensi Internal

\begin{tabular}{|c|c|c|}
\hline Konstruk & Reliabilitas Komposit & Cronbach's alpha \\
\hline Insentif & 0.932 & 0.853 \\
\hline Kinerja & 0.903 & 0.874 \\
\hline Regulasi & 0.961 & 0.919 \\
\hline Komitmen Mgt & 0.922 & 0.898 \\
\hline Akuntabilitas & 0.939 & 0.927 \\
\hline
\end{tabular}

Sumber: Output Warp-PLS, 2018 (data diolah)

\section{Hasil Pengujian Hipotesis}

Hasil pengujian hipotesis berdasarkan model persamaan struktural dalam penenlitian ini ditentukan dengan melihat nilai koefisien jalur, standard errors, $P$-values, dan effect sizes dari hasil analisis yang dilakukan. Rincian hasil pengujian hipotesis dengan menggunakan analisis SEM-PLS dapat dilihat pada Gambar 2 dan Tabel 3. 


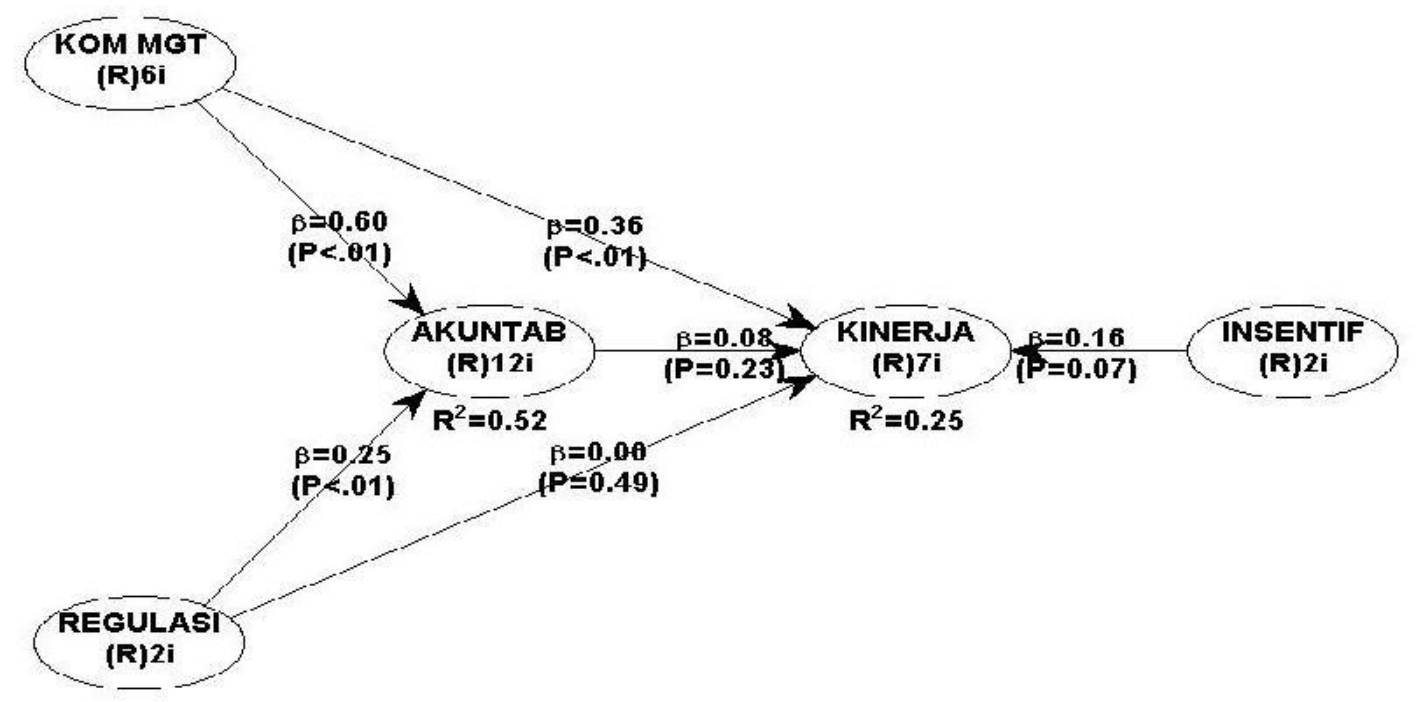

Gambar 2. Hasil Pengujian SEM-PLS

Tabel 3. Koefisien Jalur, $P$-Values, Standard errors, dan Effect sizes

\begin{tabular}{lccccc}
\hline \multicolumn{1}{c}{ Variabel } & Koefisien Jalur & P-Values & $\begin{array}{c}\text { Standard } \\
\text { errors }\end{array}$ & Effect sizes & Hasil penelitian \\
\hline Komitmen $\rightarrow$ Kinerja & 0.361 & $0.004^{* *}$ & 0.133 & 0.169 & Terdukung \\
Regulasi $\rightarrow$ Kinerja & 0.002 & 0.493 & 0.110 & 0.000 & Tidak Terdukung \\
Insentif $\rightarrow$ Kinerja & 0.158 & 0.067 & 0.105 & 0.050 & Tidak Terdukung \\
Komitmen $\rightarrow$ Akuntabilitas & 0.596 & $<0.001^{* * *}$ & 0.073 & 0.407 & Terdukung \\
Regulasi $\rightarrow$ Akuntabilitas & 0.254 & $0.002^{* *}$ & 0.087 & 0.117 & Terdukung \\
Akuntabilitas $\rightarrow$ Kinerja & 0.075 & 0.227 & 0.100 & 0.030 & Tidak Terdukung \\
\hline
\end{tabular}

** Signifikan pada level 0.01 (2-tailed)

*** Signifikan pada level 0.001 (2-tailed)

Sumber: Output Warp-PLS (data diolah)

Berdasarkan Tabel 3, dapat dilihat bahwa pengujian hipotesis pertama tentang pengaruh variabel regulasi terhadap akuntabilitas terbukti signifikan dengan nilai koefisien jalur sebesar 0.254 , $p$-value 0.002 , dan effect size yang tergolong kuat yaitu sebesar 0.117 . Hal ini berarti bahwa regulasi memiliki pengaruh positif terhadap akuntabilitas, yang mengindikasikan bahwa regulasi merupakan faktor organisasi yang relevan dengan keberhasilan pelaksanaan reformasi di organisasi pemerintah (Brignall dan Modell 2000). Akbar et al. (2012) dalam penelitiannya juga menemukan bahwa regulasi yang diukur dengan mandat legislatif memiliki hubungan positif terhadap akuntabilitas internal dan eksternal. Sedangkan hipotesis kedua yang menguji pengaruh variabel regulasi terhadap kinerja menunjukkan nilai koefisien jalur sebesar 0.002, $p$-value 0.493, dan effect size yang tergolong sangat lemah yaitu sebesar 0.000 , sehingga menyimpulkan hipotesis ini tidak terdukung.

Sementara ini, pengujian hipotesis ketiga tentang pengaruh variabel komitmen manajemen terhadap akuntabilitas menunjukkan hasil yang signifikan dan terdukung. Hal ini terlihat dari nilai koefisien jalur sebesar 0.596, $p$-value $<0.001$, dan effect size yang tergolong sangat kuat yaitu sebesar 0.407 . Begitu juga dengan hasil pada hipotesis keempat yang menunjukkan nilai koefisien jalur komitmen manajemen terhadap kinerja sebesar 0.361, p-value 0.004, dan effect size yang tergolong kuat yaitu sebesar 0.169. Hasil tersebut menyimpulkan bahwa komitmen manajemen merupakan salah satu faktor yang sangat penting dalam mendorong perwujudan akuntabilitas dan kinerja organisasi sektor publik. Temuan ini didukung oleh hasil penelitian sebelumnya yaitu Sholihin dan Pike (2009); Cavalluzzo dan Ittner (2004); Akbar et al. (2012); Primarisanti dan Akbar (2015).

Hasil pengujian hipotesis kelima tidak terdukung. Hal ini ditunjukkan dari nilai koefisien jalur Akuntabilitas terhadap Kinerja sebesar 0.075, p-value 0.227, dan effect size sebesar 0.030. Hasil ini mengindikasikan bahwa akuntabilitas yang dirasakan oleh organisasi sektor publik selama ini belum bisa menjadi sebuah alat untuk meningkatkan kemampuan pemerintah dalam menunjukkan kinerja secara lebih efisien dan efektif. Hal ini mungkin karena akuntabilitas merupakan suatu gagasan yang kompleks dan beraneka ragam, sehingga pengaruh akuntabilitas terhadap kinerja masih menjadi perdebatan, paling tidak karena kinerja sendiri sangat kompleks dan sulit diukur (Demirag dan Khadaroo 2011; Hyndman dan Eden 2001). 
Terakhir, pengujian hipotesis keenam dalam penelitian ini juga tidak terdukung terlihat dari nilai koefisien jalur Insentif terhadap Kinerja sebesar 0.158, p-value <0.067, dan effect size sebesar 0.050. Hasil pengujian ini mengungkapkan bahwa tujuan insentif dalam sistem pengukuran kinerja tidak mampu menjadi pendorong bagi SKPD untuk meningkatkan kinerjanya. Speklé dan Verbeeten (2014) dalam penelitiannya telah mengkonfirmasi hasil ini bahwa meningkatnya kinerja organisasi yang didorong oleh insentif akan tergantung pada kontraktibilitas yang tinggi, yaitu adanya kejelasan misi dan tujuan organisasi, keterukuran output, dan pengetahuan tentang proses transformasi. Sehingga hubungan langsung insentif terhadap kinerja yang tidak terdukung dalam penelitian ini mungkin dimoderasi oleh faktor lain yang tidak diuji di dalam model.

Hasil analisis data kuantitatif menunjukkan keterdukungan pada tiga hipotesis yang diajukan, sedangkan tiga hipotesis lainnya tidak terdukung. Penjelasan lebih lanjut terhadap hasil pengujian data kuantitatif tersebut dilakukan melalui pendekatan kualitatif dengan melakukan wawancara semi terstruktur dan terbuka kepada lima orang informan kunci yang dipilih berdasarkan data outlier pada analisis kuantitatif (Creswell dan Clarke 2011).

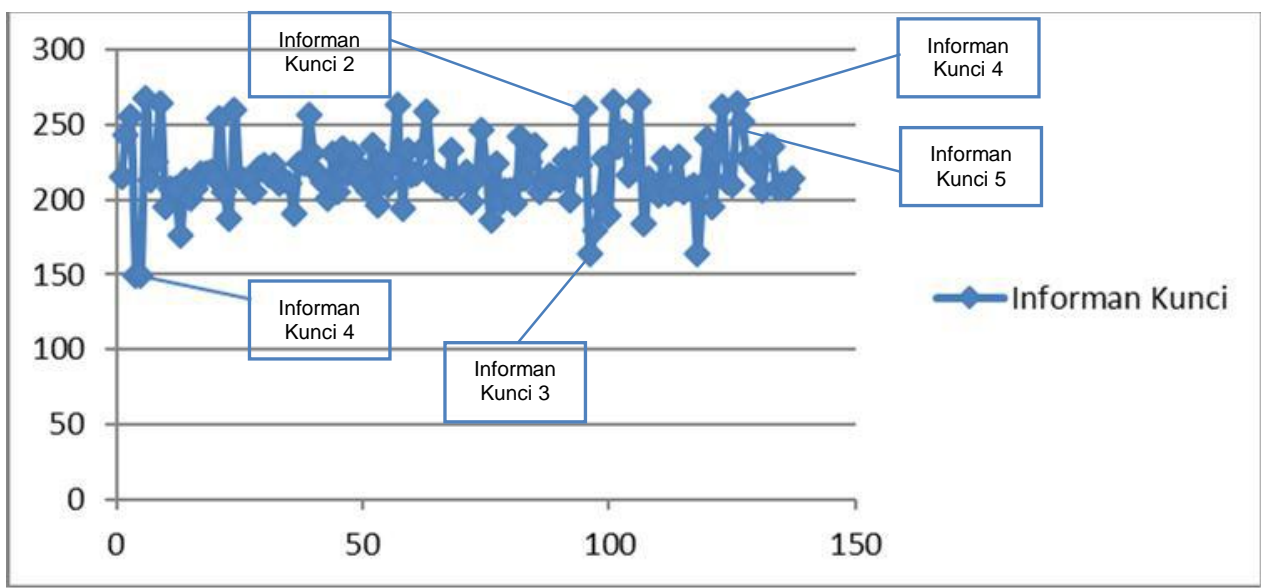

Gambar 3. Scatter Plot Sebaran Data Responden dan Informan Kunci

Wawancara dilakukan pada tanggal 24 Desember 2014 sampai 02 Januari 2015 menggunakan metode semi terstruktur dan terbuka terhadap pejabat senior SKPD. Hasil analisis scatter plot menunjukkan bahwa responden wawancara yang terpilih adalah sebanyak lima orang, terdiri dari dua orang dari Kabupaten Sleman, satu orang dari Kota Yogyakarta, dan dua orang dari Kabupaten Bantul. Pejabat tersebut merupakan pejabat senior yang memiliki jabatan eselon III (dua orang) dan eselon IV (tiga orang) yang menempati berbagai macam posisi, seperti: Sekretaris, Kepala Bidang Tenaga Kerja, Kepala Seksi Perencanaan dan Pelaporan, Kepala Subbidang litbang ekonomi sosial budaya, serta Kepala Sub-bagian Analisis Jabatan dan Aparatur. Responden tersebut berasal dari berbagai macam instansi yang berbeda (satu dari sekretariat daerah, tiga dari dinas, dan satu dari kecamatan). Ada tiga orang laki-laki dan dua orang perempuan yang terlibat dalam wawancara tersebut. Lamanya waktu wawancara yang dilakukan berkisar antara 20-30 menit.

Wawancara tersebut terkait dengan isomorfisma institusional yang terjadi dalam praktik pelaksanaan akuntabilitas dan kinerja organisasi pemerintah. Teori institusional mengatakan bahwa organisasi mengejar legitimasi dengan menyesuaikan pada tekanan isomorfik yang ada di lingkungannya (Ashworth et al. 2009). Dalam konteks organisasi pemerintah di Indonesia, ada kewajiban setiap organisasi/lembaga pemerintah untuk melaporkan kinerjanya kepada pemerintah pusat sesuai dengan inpres nomor 7 tahun 1999. Regulasi dan peraturan tersebut merupakan sebuah bentuk isomorfisma koersif yang menjadi salah satu faktor pendorong praktik penerapan akuntabilitas dan kinerja pada organisasi sektor publik (lembaga pemerintah). Talbot (2008) juga mengungkapkan hal yang sama bahwa para manajer publik menilai undang-undang sebagai salah satu penggerak utama suatu perubahan. Pernyataan ini diperkuat dengan hasil wawancara berikut:

Secara manajemen kita itu kan bekerja selalu didasari yang namanya aturan, itu dasar utama kita bekerja, sehingga kalo dikaitkan dengan peraturan yang menyangkut peningkatan kinerja itu jelas sangat erat, sangat mendukung, karena itu menjadi bagian-ya istilahnya rambu-rambu kita dalam bekerja, karena kita posisi kan sekarang sudah jelas itu harus ditentukan sesuai dengan-kalo di keuangan itu istilahnya DPA (dokumen pelaksanaan anggaran), itu yang menjadi kunci, itu istilahnya kontrak kerja kita. Sehingga kaitannya dengan aturan itu yang menyangkut peningkatan kinerja itu jelas sangat berdampak (R127, Sekretaris Kecamatan). 
Berdasarkan hasil wawancara tersebut, regulasi atau aturan menjadi dasar utama bagi aparat pemerintah untuk menjalankan pekerjaan. Dalam konteks akuntabilitas dan kinerja, regulasi yang berlaku adalah instruksi presiden nomor 7 tahun 1999 yang terkait dengan kewajiban organisasi pemerintah untuk menyampaikan laporan akuntabilitas kinerja instansi pemerintah (LAKIP). Dalam penelitian ini, ada temuan menarik terkait dengan LAKIP yang disampaikan oleh organisasi pemerintah. Berikut hasil temuan wawancara kepada responden:

Yang serius tidak pernah terjadi (menggunakan informasi yang ada dalam LAKIP), yang terjadi hanya formalitas. Jadi LAKIP itu harus disetor tepat waktu, sesuai format, sesuai begini, begini, disetor ke DEPDAGRI (Departemen Dalam Negeri, Red), ke BAPPENAS (Badan Perencanaan Pembangunan Nasional, Red), tapi kenyataannya ya cuma disetor, informasinya tidak digunakan untuk apa-apa. Apakah misalnya capaian kinerja Standar Pelayanan Minimum (SPM) harus sekian, itu bermakna, kadang-kadang enggak sih. Contohnya, kita punya data, data dari tahun ke tahun, prosentase rumah yang tidak berizin, sejak dinas perizinan itu ada, itu bukannya turun, prosentasenya naik. Berarti bahan itu, data itu, laporan itu, tidak digunakan apa-apa oleh pemerintah ini untuk mengambil tindakan, harusnya kan tindakannya jelas (R4, Kasubbid litbang ekonomi sosial budaya).

Berdasarkan hasil wawancara di atas, terungkap bahwa laporan akuntabilitas kinerja instansi pemerintah yang dilaporkan kepada pemerintah pusat (DEPDAGRI dan BAPPENAS) hanya sebatas formalitas. Informasi yang terkandung dalam LAKIP tidak digunakan oleh organisasi pemerintah sebagai umpan balik untuk memperbaiki kinerja dan akuntabilitas maupun bentuk pengambilan keputusan lainnya. Hal ini mengindikasikan bahwa kinerja yang dilaporkan dalam LAKIP mungkin tidak mencerminkan kinerja sesungguhnya, melainkan lebih pada kinerja semu. Hasil penelitian ini juga diperkuat oleh Nurkhamid (2008) yang mengatakan bahwa instansi pemerintah memiliki kecenderungan untuk melaporkan kinerja yang baik secara berlebihan, sedangkan program yang gagal cenderung disembunyikan. Laporan kinerja yang selama ini dibuat oleh instansi pemerintah hanya sekedar untuk memenuhi kewajiban persyaratan regulasi dan peraturan, tidak secara substantif mencerminkan kinerja yang terjadi di lapangan. Hal ini kemudian bisa menyesatkan publik sebagai pengguna informasi dan pada akhirnya berakibat pada ekspektasi publik yang berlebihan terhadap instansi pemerintah (Ahyaruddin dan Akbar 2016, 2018).

Selain itu, era reformasi sekarang ini memunculkan banyak regulasi baru dari pemerintah pusat yang dapat berdampak terhadap adanya tumpang tindih atau bahkan bertentangan antar aturan yang satu dengan lainnya pada pemerintah daerah. Hal ini kemudian bisa memunculkan kebingungan kepada pelaku pemerintahan (pejabat) untuk melaksanakan aturan tersebut. Sehingga, yang terjadi adalah mereka mengikuti atau meniru organisasi lainnya dalam membuat laporan kinerja.

Dalam pembuatan laporan kinerja, kami mengacu pada Pemda, dan ada koordinasi antar instansi dan itu dikoordinir oleh Bappeda (R125, Kabid Tenaga Kerja).

Selama ini format laporan di tingkat SKPD belum begitu jelas, perlu dikembangkan template untuk tingkat SKPD (R96, Kasi Perencanaan dan Pelaporan).

\section{Simpulan}

Hasil pengujian kuantitatif menemukan bukti bahwa komitmen manajemen berpengaruh signifikan terhadap akuntabilitas dan kinerja. Selain itu, regulasi juga ditemukan memberikan pengaruh signifikan terhadap akuntabilitas. Hasil analisis kualitatif menunjukkan bahwa isomorfisma institusional terjadi dalam praktik penerapan akuntabilitas dan kinerja organisasi sektor publik. Isomorfisma koersif dalam bentuk regulasi sebagai salah satu bentuk isomorfisma institusional menjadi faktor utama pendorong organisasi melakukan perubahan. Hasil analisis yang dilakukan menyimpulkan bahwa isomorfisma koersif yang terjadi dalam proses penerapan akuntabilitas dan kinerja organisasi pemerintah menciptakan kinerja semu karena organisasi pemerintah dalam melaporkan kinerjanya hanya sebatas formalitas untuk memenuhi kewajiban regulasi. Selain itu, informasi yang terkandung dalam LAKIP juga tidak digunakan dalam proses pengambilan keputusan.

Penelitian ini memberikan kontribusi terhadap pengembangan teori institusional sebagai sebuah kerangka dasar yang mampu menjelaskan praktik penerapan akuntabilitas dan kinerja di sektor publik serta memperluas hasil penelitian sebelumnya yang pernah dilakukan. Selain itu, penggunaan metode campuran dalam penelitian ini memberikan manfaat besar dan bisa memberikan hasil penelitian yang kuat (robust). Pendekatan ini mampu menjawab permasalahan penelitian yang kompleks dan bisa menjelaskan berbagai hal dan situasi secara lebih detil dibandingkan hanya satu pendekatan penelitian. Terakhir, penelitian ini memberikan implikasi 
kebijakan dimana organisasi sektor publik perlu memberikan perhatian yang besar terhadap komitmen manajemen. Hal ini karena komitmen manajemen memberikan kontribusi besar terhadap peningkatan kinerja dan akuntabilitas. Para pembuat kebijakan perlu memperbesar upaya mereka dalam mendorong lembaga pemerintah untuk meningkatkan akuntabilitas dan kinerja pelayanan publik demi terwujudnya efektifitas dan kesejahteraan sosial.

Penelitian ini memiliki beberapa keterbatasan. Pertama, penelitian ini dilakukan hanya pada organisasi sektor publik di Daerah Istimewa Yogyakarta dengan membatasi ruang lingkup pada SKPD. Sehingga hasil penelitian ini mungkin hanya bisa digeneralisasikan pada area tersebut. Penelitian selanjutnya disarankan memperbesar area populasi dan memperluas ruang lingkup organisasi sektor publik, tidak hanya SKPD, tetapi juga organisasi sektor publik lain yang memberikan pelayanan kepada publik seperti rumah sakit dan lembaga pendidikan. Kedua, operasionalisasi variabel akuntabilitas dalam penelitian ini terbatas pada akuntabilitas internal dan eksternal. Sementara akuntabilitas sendiri bisa didefinisikan dalam banyak dimensi, seperti: akuntabilitas politik, akuntabilitas publik, akuntabilitas manajerial, akuntabilitas profesional, dan akuntabilitas personal (Sinclair 1995). Oleh karena itu, penelitian selanjutnya diharapkan bisa mengidentifikasi kelima dimensi akuntabilitas tersebut dalam hubungannya dengan kinerja organisasi.

\section{Ucapan Terima Kasih}

Penulis mengucapkan terima kasih kepada Public Sector Governance Fakultas Ekonomika dan Bisnis Universitas Gadjah Mada yang telah memberikan bantuan dana dalam penelitian ini serta kepada para responden yang bersedia menjadi informan sehingga penelitian ini bisa selesai dengan baik.

\section{Daftar Referensi}

Ahyaruddin, M. 2015. Hubungan antara penggunaan sistem pengukuran kinerja, faktor-faktor organisasional, akuntabilitas, dan kinerja organisasi sektor publik. Universitas Gadjah Mada.

Ahyaruddin, M., dan R. Akbar. 2016. The relationship between the use of a performance measurement system, organizational factors, accountability, and the performance of public sector organizations. Journal of Indonesian Economy and Business 31 (1): 1-22. http://prisma.lppm.ugm.ac.id/publication/27246.

2018. Indonesian local government's accountability and performance: the isomorphism institutional perspective. Jurnal Akuntansi Dan Investasi 19 (1): 1-11. https://doi.org/10.18196/jai.190187.

Akbar, R. 2011. Performance measurement and accountability in Indonesian local government. Curtin University. curtin university. https://doi.org/10.1108/09513559910308039.

Akbar, R., R. A. Pilcher, dan B. Perrin. 2015. Implementing performance measurement systems: Indonesian local government under pressure. Qualitative Research in Accounting \& Management 12 (1): 3-33.

Akbar, R., R. Pilcher, dan B. Perrin. 2012. Performance measurement in Indonesia: the case of local government. Pacific Accounting Review 24 (3): 262-291. https://doi.org/10.1108/01140581211283878.

Ashworth, R., G. Boyne, dan R. Delbridge. 2009. Escape from the iron cage? organizational change and isomorphic pressures in the public sector. Journal of Public Administration Research and Theory 19 (1): 165-187. https://doi.org/10.1093/jopart/mum038.

Brignall, S., dan S. Modell. 2000. An institutional perspective on performance measurement and management in the new public sector. Management Accounting Research 11 (3): 281-306. https://doi.org/10.1006/mare.2000.0136.

Cavalluzzo, K. S., dan C. D. Ittner. 2004. Implementing performance measurement innovations: evidence from government. Accounting, Organizations and Society 29 (3-4): 243-267. https://doi.org/10.1016/S03613682(03)00013-8.

Chenhall, R. H. 2003. Management control systems design within its organizational context: findings from contingency-based research and directions for the future. Accounting, Organizations and Society 28 (23):127-168. https://doi.org/10.1016/S0361-3682(01)00027-7.

Christensen, T., dan P. Lægreid. 2014. Performance and accountability—a theoretical discussion and an empirical assessment. Public Organization Review 15 (2): 207-225. https://doi.org/10.1007/s11115-013-0267-2.

Creswell, J., dan V. Clarke. 2011. Designing and conducting mixed methods research. Sage Publications. 2nd Ed. 
USA. https://doi.org/10.1111/j.1753-6405.2007.00096.x.

Demirag, I., dan I. Khadaroo. 2011. Accountability and value for money: a theoretical framework for the relationship in public-private partnerships. Journal of Management and Governance 15 (2): 271-296. https://doi.org/10.1007/s10997-009-9109-6.

Dimaggio, P. J., dan W. W. Powell. 1983. The iron cage revisited: institutional and collective rationality in organizational fields. American Sociological Review 48 (2): 147-160.. https://doi.org/10.2307/2095101.

Dubnick, M. 2005. Accountability and the promise of performance: in search of the mechanisms. Public Performance \& Management Review 28 (3): 376-417. https://doi.org/10.2307/3381159.

Dunk, A. S., dan A. F. Lysons. 1997. An analysis of departmental effectiveness, participative budgetary control processes and environmental dimensionality within the competing values framework: a public sector study. Financial Accountability \& Management 13: 1-15. https://doi.org/10.1111/1468-0408.00023.

Erro, G. A., dan J. A. C. Sánchez. 2012. Joining the un global compact in Spain: an institutional approach. Revista de Contabilidad - Spanish Accounting Review 15 (2): 311-355. https://doi.org/10.1016/S11384891(12)70047-X.

Hansen, D. R., dan M. M. Mowen. 2006. Cost managment accounting \& control. Thompson South-Western. USA.

Hyndman, N., dan R. Eden. 2001. Rational management, performance targets and executive agencies: views from agency chief executives in Northern Ireland. Public Administration 79 (3): 570-598. https://doi.org/10.1111/1467-9299.00270.

Ichniowski, C., K. Shaw, dan G. Prennushi. 1997. The effects of human resource management practices on productivity: a study of steel finishing lines. The American Economic Review 87 (3): 291-313. https://doi.org/10.2307/2951347.

lyoha, F. O., dan D. Oyerinde. 2010. Accounting infrastructure and accountability in the management of public expenditure in developing countries: a focus on Nigeria. Critical Perspectives on Accounting 21 (5): 361-373. https://doi.org/10.1016/j.cpa.2009.06.002.

Manafe, M. W. N., dan R. Akbar. 2014. Accountability and performance: evidence from local government. Journal of Indonesian Economy and Business 29 (1): 56-73. http://ezproxy.auckland.ac.nz/login?url=http://search.proquest.com/docview/1651366044? accountid=8424 http://openurl.auckland.ac.nz/resolve?url_ver=Z39.882004\&rft_val_fmt=info:ofi/fmt:kev:mtx:journal\&genre=article\&sid=ProQ:ProQ\%3Aeducation\&atitle=Accou nta.

Newberry, S., dan J. Pallot. 2004. Freedom or coercion? NPM incentives in New Zealand central government departments. Management Accounting Research 15 (3): 247-266. https://doi.org/10.1016/j.mar.2004.03.004.

Nurkhamid, M. 2008. Implementasi inovasi sistem pengukuran kinerja instansi pemerintah. Jurnal Akuntansi Pemerintah 3 (1): 45-75.

Pollitt, C. 2008. Performance Blight and the Tyranny of Light? Accountability in Advanced Performance Measurement Regime. Paper dipresentasikan pada the Kettering Foundation Symposium on accountability, May 22-23, 2008 di Dayton, Ohio.

Price, J. L., A. H. Van de Ven, dan D. L. Ferry. 1981. Measuring and assessing organizations. Administrative Science Quarterly 26 (2): 324. https://doi.org/10.2307/2392488.

Primarisanti, H., dan R. Akbar. 2015. Factors influencing the success of performance measurement: evidence from local government. Journal of Indonesian Economy and Business 30 (1): 56-71.

Schillemans, T. 2011. Does horizontal accountability work? evaluating potential remedies for the accountability deficit of agencies. Administration and Society 43 (4): 387-416. https://doi.org/10.1177/0095399711412931.

Sholihin, M., dan R. Pike. 2009. Fairness in performance evaluation and its behavioural consequences. Accounting and Business Research 39 (4): 397-413. https://doi.org/10.1080/00014788.2009.9663374.

Sinclair, A. 1995. The chameleon of accountability: forms and discourses. Accounting, Organizations and Society 
20 (2-3): 219-237. https://doi.org/10.1016/0361-3682(93)E0003-Y.

Sofyani, H., dan R. Akbar. 2013. Hubungan faktor internal institusi dan implementasi sistem akuntabilitas kinerja instansi pemerintah (SAKIP) di pemerintah daerah. Jurnal Akuntansi dan Keuangan Indonesia 10 (2): 184-205. https://doi.org/10.21002/jaki.2013.10.

2015. Hubungan karakteristik pegawai pemerintah daerah dan implementasi sistem pengukuran kinerja: perspektif ismorfisma institusional. Jurnal Akuntansi dan Auditing Indonesia 19 (2): 153-173. https://doi.org/10.20885/jaai.vol19.iss2.art6.

Speklé, R. F., dan F. H. M. Verbeeten. 2014. The use of performance measurement systems in the public sector: effects on performance. Management Accounting Research 25 (2): 131-146. https://doi.org/10.1016/j.mar.2013.07.004.

Talbot, C. 2008. Performance regimes-the institutional context of performance policies. International Journal of Public Administration 31 (14): 1569-1591. https://doi.org/10.1080/01900690802199437.

Verbeeten, F. H. M. 2008. Performance management practices in public sector organizations: impact on performance. Accounting, Auditing \& Accountability Journal 21 (3): 427-454. https://doi.org/10.1108/09513570810863996.

Wang, X. 2002. Assessing administrative accountability: results from a national survey. American Review of Public Administration 32 (3): 350-370. https://doi.org/10.1177/0275074002032003005.

Wijaya, A. H. C., dan R. Akbar. 2013. The influence of information, organizational objectives and targets, and external pressure towards the adoption of performance measurement system in public sector. Journal of Indonesian Economy and Business 28 (1): 62-83.

Williams, J. J., N. B. Macintosh, dan J. C. Moore. 1990. Budget-related behavior in public sector organizations: some empirical evidence. Accounting, Organizations and Society 15 (3): 221-246. https://doi.org/10.1016/03613682(90)90006-G. 